\title{
Palsy of the Contralateral Abducens Nerve after Aneurysm Surgery and Temporal Meningioma in the Presence of Petroclival Meningioma: A Case Report
}

\section{Paresia de nervo abducente contralateral pós-cirurgia de aneurisma e de meningioma temporal em presença de meningioma petroclival: relato de caso}

\author{
Pedro Ferreira Paiva Moreira ${ }^{1}$ Anderson Rodrigo Souza ${ }^{1}$ Manoel Jacobsen Teixeira ${ }^{1}$ \\ Eberval Gadelha Figueiredo ${ }^{1}$ \\ ${ }^{1}$ Division of Neurosurgery, Faculdade de Medicina, Universidade de \\ Address for correspondence Pedro Ferreira Paiva Moreira, \\ São Paulo, São Paulo, SP, Brazil \\ Arq Bras Neurocir 2018;37:148-150. \\ Universidade de São Paulo, Av. Dr. Arnaldo, 455 - Cerqueira César, \\ São Paulo, SP, 01246-903, Brazil (e-mail: pedro.moreira@fm.usp.br).
}

\begin{abstract}
The sixth abducens nerve is subject to injury after rare complications of intracranial hypotension caused by procedures such as dural punctures and spinal surgeries. The

Keywords

- abducens nerve palsy

- petroclival meningioma

- intracranial aneurysm

\section{Resumo}

Palavras-chave

- paresia de nervo abducente

- meningioma petroclival

- aneurisma intracraniano purpose of this case report is to discuss the mechanism of nerve palsy in these situations. Therefore, we describe a case of onset of contralateral sixth cranial nerve palsy after intracranial aneurysm and temporal meningioma surgery. Moreover, in this case there is a singularity due to the presence of the petroclival meningioma that amplified the unfolding of the lesion.

O sexto nervo abducente está sujeito a lesões após raros eventos de hipotensão intracraniana gerada por procedimentos como punções de dura-máter e cirurgias de coluna. O propósito deste relato de caso é discutir o mecanismo da paralisia deste nervo nestas situações. Para isso, descrevemos um caso de aparecimento de paresia do sexto nervo craniano contralateral após cirurgia de aneurisma intracraniano e de meningioma temporal. Além do mais, neste caso há uma singularidade em razão da presença do meningioma petroclival contralateral, que amplificou o desdobramento da lesão.
\end{abstract}

\section{Introduction}

After surgeries in places near the sixth abducens nerve, ipsilateral nerve palsy may occur due to injury by surgical manipulation. However, palsy of the sixth cranial nerve is also a rare complication following surgeries and procedures that can cause cerebrospinal fluid (CSF) hypotension in areas distant from the nerve pathway. In the literature, there are descriptions of this occurrence mainly in dural lesion spinal surgeries $^{1,2}$ and dura mater puncture procedures, ${ }^{3}$ such as lumbar punctures and spinal anesthesia.

The authors present a case of contralateral abducens nerve palsy after left middle cerebral artery aneurysm surgery and left temporal meningioma, differing from most of the literature reports describing lesions of the sixth cranial nerve following procedures and surgeries of the spine. Our objective is to discuss the mechanisms of the appearance of abducens nerve palsy when the site of manipulation is remote, along received

February 8, 2018

accepted

March 13, 2018

published online

May 2, 2018
DOI https://doi.org/

$10.1055 / \mathrm{s}-0038-1648214$ ISSN $0103-5355$.
Copyright $\odot 2018$ by Thieme Revinter

Publicações Ltda, Rio de Janeiro, Brazil
License terms

(c) $(1) \$$ 


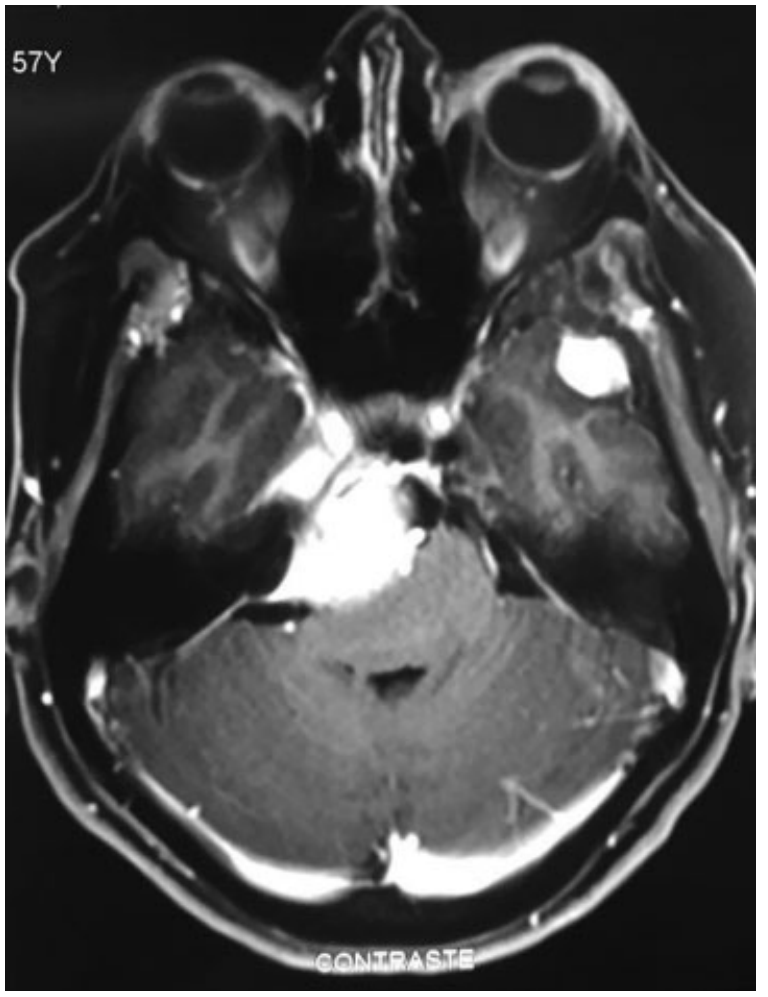

Fig. 1 Gadolinium-enhanced T1-weighted axial magnetic resonance image showing the left temporal meningioma and the right petroclival meningioma.

with the particularities present in this case due to the presence of a petroclival meningioma ipsilateral to the injured nerve.

\section{Case Report}

The patient is a 49-year-old woman. Her initial symptom was a headache. As part of the diagnostic routine, a magnetic resonance imaging of the skull was requested. In this examination, a left temporal meningioma, a left cerebral artery aneurysm and a right petroclival meningioma were revealed (- Figs. 1, 2).

After the identification of these lesions, the patient opted for the surgery of only the left temporal meningioma and left

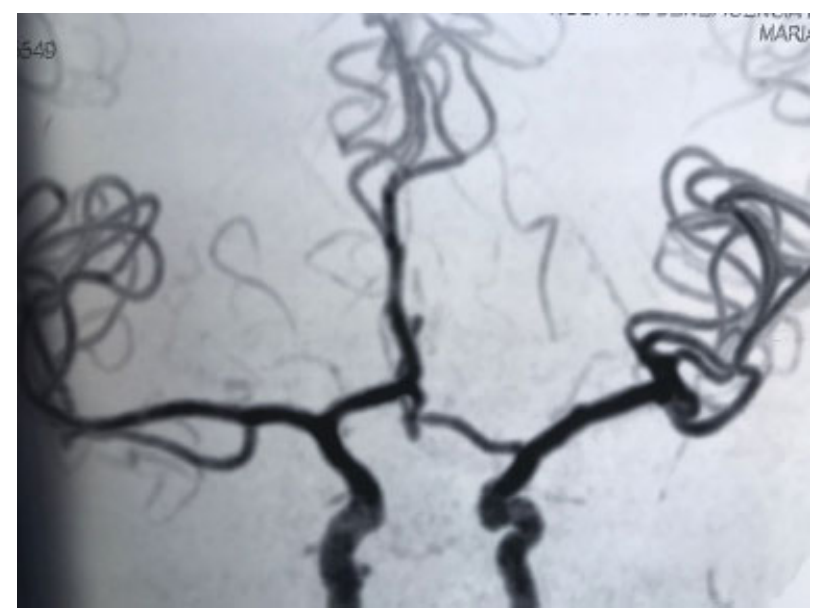

Fig. 2 Arteriography showing the left cerebral artery aneurysm. cerebral artery aneurysm. For this, a pterional craniotomy was performed on the left hemisphere of the brain.

In the postoperative period, the patient developed abducens nerve palsy on the right side, contralateral to the surgery. After 3 months, the function of this nerve was completely recovered spontaneously.

\section{Discussion}

Abducens nerve palsies in cases of procedures performed in distant sites were described in the literature after lumbar puncture (diagnostic and therapeutic), inadvertent lumbar puncture during epidural anesthesia, spinal anesthesia, CSF shunt, intrathecal drug delivery, myelography, and lumbar drainage. ${ }^{4}$ Cases of this occurrence have also been reported due to spinal surgery. ${ }^{5}$ These procedures may lead to intracranial hypotension due to CSF drainage, ${ }^{6}$ which would be the explanation for nerve damage. This is due to the anatomy and the long course of the sixth cranial nerve and its relation to the base of the skull.

The abducens nerve innervates the lateral rectus muscle, whose function is the abduction of the eye. Its nucleus lies on the dorsal surface of the pons ventrally to the floor of the fourth ventricle. Throughout its course, the nerve has three points of pronounced curvature. ${ }^{7}$ When emerging from the lower part of the pons, the nerve performs its first sharp curve in the upper direction. It then goes through the subarachnoid space superiorly along the clivus and through the Dorello channel. This channel lies between the petrosphenoidal ligament (Gruber ligament) and the apex of the petrous part of the temporal bone and fixes the nerve. ${ }^{8}$ Farther, the nerve curves for the second time, through the Dorello canal, around the apex of the petrous part of the temporal bone and penetrates into the cavernous sinus. In this region, it runs laterally to the internal carotid artery (around which it makes its third curvature) and enters the orbit through the superior orbital fissure. Soon after, it innervates the lateral rectus muscle.

In the course of its long intracranial path, the abducens nerve is subjected to mechanical forces of traction and compression. In the aforementioned situations of intracranial hypotension by CSF drainage, the nerve loses its support and remains stretched. This is due to its anatomical relationships with the base of the skull and its long and tortuous trajectory. The first sharp curve of the nerve in the petroclival region when piercing the dura and entering the Dorello canal is the region most susceptible to nerve stretching. In this area, the acute angle near the nerve fixation region in the canal favors the risk of traction with the loss of brainstem support by intracranial hypotension. ${ }^{9}$ This stretching would injure the nerve, generating its palsy.

However, reports in the literature point to the palsy of the sixth cranial nerve by this mechanism mostly through procedures and surgeries in the spine with dural puncture, not intracranial surgeries. In this case, the drainage of the CSF and the opening of the cisterns during surgery was sufficient to cause nerve damage.

We believe that the particularity of the case lies in the presence of the petroclival meningioma ipsilateral to the 
injured nerve. The presence of petroclival meningioma alone can generate an abducens nerve palsy due to traction and compression injury, ${ }^{10}$ but in this case, the palsy manifested only after the aneurysm and temporal meningioma surgery. As the nerve region susceptible to stretching is just along its tortuous path through the petroclival region, the presence of the tumor in this area would amplify the nerve traction. Thus, both the relative CSF imbalance and the consequent loss of nerve support in the brainstem and the compression caused by the petroclival meningioma were responsible, in this case, for the palsy of the nerve contralateral to the surgery and ipsilateral to the unresected tumor.

\section{Conclusion}

Palsy of the abducens nerve, even when the site of manipulation is remote, is characterized as a rare complication after surgeries and procedures with dural puncture. With relative intracranial hypotension due to CSF imbalance, the nerve is subject to stretching because of its long and tortuous course. Moreover, in this case, the petroclival meningioma contralateral to the surgery may have contributed to transient abducens nerve palsy.

\section{Conflicts of Interest}

The authors declare that there are no conflicts of interest.

\section{References}

1 Sandon LH, Choi G, Park E, Lee HC. Abducens nerve palsy as a postoperative complication of minimally invasive thoracic spine surgery: a case report. BMC Surg 2016;16(01):47

2 Cho DC, Jung ES, Chi YC. Abducens nerve palsy after lumbar spinal fusion surgery with inadvertent dural tearing.J Korean Neurosurg Soc 2009; 46(06):581-583

3 Nishio I, Williams BA, Williams JP. Diplopia: a complication of dural puncture. Anesthesiology 2004;100(01):158-164

4 Cain RB, Patel NP, Hoxworth JM, Lal D. Abducens palsy after lumbar drain placement: a rare complication in endoscopic skull base surgery. Laryngoscope 2013;123(11):2633-2638

5 Joo JD, Yoon SH, Kim KJ, Jahng TA, Kim HJ. Isolated abducens nerve palsy due to cerebrospinal fluid leakage following lumbar discectomy: a rare clinical entity. Eur Spine J 2013;22(Suppl 3): S421-S423

6 Quintero I, Candamil Á, Mejía Mantilla J, Medina H, Ariza Cadena F. Síndrome de hipotensión endocraneana: ¿una cefalea pospunción dural? Rev Colomb Anestesiol 2013;41(01):57-60

7 Umansky F, Elidan J, Valarezo A. Dorello's canal: a microanatomical study. J Neurosurg 1991;75(02):294-298

8 Romero FR, Ramos JG, Chaddad-Neto F, Bethencourt JM, de Oliveira E. Microsurgical anatomy and injuries of the abducens nerve. Arq Neuropsiquiatr 2009;67(01):96-101

9 Azarmina M, Azarmina H. The six syndromes of the sixth cranial nerve. J Ophthalmic Vis Res 2013;8(02):160-171

10 Shono T, Mizoguchi M, Yoshimoto K, Amano T, Natori Y, Sasaki T. Clinical course of abducens nerve palsy associated with skull base tumours. Acta Neurochir (Wien) 2009;151(07):733-738, discussion 738 